\title{
Citizens and media cultures: hidden behind democratic formality ${ }^{1}$
}

\author{
Rosa María Alfaro Moreno \\ Universidad de Lima, Peru
}

\begin{abstract}
The relationship between culture and mass media has received much attention among communication scholars in Latin America, especially during the 1980s and 1990s. This period witnessed a shift from understanding culture and mass communication as domination, to an exploration of the complex and politically nuanced roles played by the mass media within the cultural and political fabrics of the region. As such, the ideological and deterministic moorings of the old debates were considerably softened, as writers such as Martín-Barbero redefined the media in terms of cultural mediations. From this perspective, cultural mediations shape the manner in which subjects articulate their relationship to modernity. This article continues this agenda by exploring the complex relationship between culture, politics and democracy.
\end{abstract}

KEY WORDS

citizen - civil society - culture - democracy - Latin America - mass media

Theorizing the complex relationships between subjects and modernity has produced new conceptual perspectives, such as: cultural hybridity (García Canclini, 1989); the study of media and media institutions and their diverse manners of interacting with modernity (Brunner, 1994); the incorporation of popular cultures into mass culture (Alfaro et al., 1990); and the relationship between culture and globalization as a world phenomenon (Ortiz, 1997). In all these theoretical perspectives, the audience has emerged as a communicative and cultural agent (Orozco, 1996) and a variety of media genres have been studied. From this research popular culture emerged as a dense field of popular imaginaries, including a politics of recognition and redefinitions of the political (Rey, 1998).

Global Media and Communication [1742-7665(2006)2:3] Volume 2(3): 299-313 
Many scholars contributed to this stream of intellectual production, which sought to challenge and rethink the relationship between mass communication and culture. This article continues this agenda by defining culture in its relationship to politics and democracy as 'the particular manner in which a specific human community experiences, imagines, and represents its capacity to coexist'. From this perspective, the cultural agent is understood as 'the subject who conceives him/ herself as the origin and source of meaning of his/her actions, and who has the collective conditions within which to imagine and reject them'. ${ }^{2}$

For most Latin American citizens, the mass media provide the primary political capital they have access to, much more so if we consider today's deterioration of political parties and institutions. In short, it is here that they now learn about politics and their roles within it. The understanding of notions of state, authority and self-esteem are particularly confronted by television, or by the new graphic space offered at the newspaper kiosks, in which sensationalism predominates. By means of their support, people define affections, affinities and criticisms, and are informed about what democracy is, and what is good or bad. In the interaction with these headlines, they accept or reject leaders, and choose or choose not to become involved with the public interest. Or, at least in their imaginations, they create what is actually important, distinguishing it from what is not.

The media not only put citizens in interaction with the hermeneutic process, but also allow them to create their own political culture, which moves between the real and the symbolic and between pragmatic reason and desire. It is within these convergences that community specificities are activated in an effort to constitute themselves as subjects with certain power. Both culture and politics thus get involved in a highly meaningful rapprochement and interdependence with political action and participation. However, not all citizens are similar; their specific biographies emerge from differentiated modes of interaction with the social and the political and it is these historical particularities that shape each person's basic cultural capital, which ultimately frames every act of reading, seeing or listening to texts of others, and their appropriation or indifference. From these singularities, citizens establish fragile connections between their role as consumers and as citizens, constantly modifying their political culture and behaviour. From this perspective, our notions of culture become more itinerant and changeable, less essentialized and ideological; the focus is now more on convergences which constitute social and cultural positions and life experiences shaped by the invitation to consume information and values. Within 
this context, we can't continue treating the media as merely a tool for politics, but rather as fundamental sources of citizens' definitions of democracy and power.

\section{Mass media and democratic political culture: disconnected and disconcerting}

I understand political culture as a forum/place in which subjectivities emerge from differentiated relations with democratic political power. Political culture is constituted by different versions of common sense, by different sensitivities vis-a-vis others' or one's own power, and by iconic and value-based interpretations of the relationships between rulers and ruled. Central to my analysis of political culture is the notion of selfempowerment as well as one's collective power - notions felt very differently depending upon the subject's location vis-a-vis the centre of power. Thus my analysis revolves around citizens' symbolic appropriations of politics, and how these meanings shape their willingness to participate in political processes and to be involved (or not) in exercising power. I am interested in political culture when understood as the ethical assumptions that regulate all relationships among citizens, between them and the authorities, and with the existing political order. That is, political culture is where people render democracy meaningful in their everyday lives (or do not). In this era, what citizens know about democracy is what the media have allowed them to come in contact with, as the media have become the only spaces in which authorities, leaders and citizens may encounter each other.

In Latin America political culture feeds on multiple cultural matrices. However, in terms of civic engagement with politics, the national and local spheres weigh significantly more. While Latin American citizens tend to seek out the global diaspora for their entertainment, national news broadcasts are still at the core of their information sources. Television consumers, for example, turn to cable TV in search of a wider offering (whenever such service is available), except when it comes to news and information. While the world news sections of newspapers and TV news are quite poor and gradually becoming smaller, our media give more coverage to local news, even to the point of making the personal lives of national and local political figures the focus of information, and thus risk becoming mere broadcasters of scandal and gossip (except at such moments of profound human cost as the war in Iraq or international catastrophes). As media discourses and politics become fused in citizens' minds, these tendencies compound an already 
evident distrust of politics by adding more elements that can serve to spark collective anger and undermine people's belief in democracy, thus cultivating wide and deep disillusionment about any possibility of change. In Latin American civil society many people perceive democracy as disorder, inequity and corruption. Although responsible citizens are indispensable for democratic life, we have to begin from where citizens actually are, with all their doubts and distrust, with their assessment of democracy deeply grounded in scepticism.

The motto Liberty, Equality, Fraternity is the best definition of democracy, because it brings together political elements with social or moral ones. It reveals that, for democracy to be real, a political system is defined by the relationships that it establishes among the individuals, the social organization and the political power, and not only by some institutions and some ways of functioning (Touraine, 1998: 112). Defined this way, democracy is understood as constructed on a specific type of relationship between the state and civil society, highlighting its communicative nature. Yet, Latin American democracies are far from this. The communicative nature of democracy is not put at the service of the citizens and their relations to each other and to the state. Instead, the focus is on making sure that formal democratic organizations are efficient so that the proper performance of the market can be guaranteed.

Citizenship cannot exist without the presence and participation of citizens capable of working together, respecting and recognizing each other. 'The status of citizen is, therefore, the official acknowledgement of the individual's integration into the political community, a community that, from the beginning of modernity, takes the shape of a national state and the rule of law' (Cortina, 1977: 39). The core of the matter is how different actors assume and value political participation and democratic practice - the form these ideas take as they enter citizens' sphere of subjectivity. Unfortunately, democratic practice is seen more as a survival strategy than as a means for political transformation.

It is also true that collective citizenship is not simply a result of individual consciousness. Touraine reminds us that the citizen is the protagonist of democracy, which in turn is based on 'reason, freedom and memory, all at the same time. These three dimensions correspond to those of democracy; the realization of a collective identity should translate into a political organization that articulates the interests and values of all different social groups' (Touraine, 1998: 185). This definition binds together both individuals and their organizations, considering them as capable of reasoning, of exercising their freedom and of incorporating their lived experience as the raw material for 
political practice. That is, collectivities are not important in themselves, but rather in their integration into political organization, as they articulate their demands to the life of a larger community. Thus the private and the public exist in continuous tension in the construction of common interests, and - given the complexity of the many articulations and dislocations between the private and public worlds - this relationship is reformulated each step of the way, according to each event or experience (Alfaro, 2001).

It is important to recognize that today the media constitute a crucial source of civic education and legitimization of democratic power. Political elites legitimize themselves or join dissident discourses through their interactions with newspapers, magazines, radio and television. Notions of political authority, political values and general understanding of a nation's political institutions are consolidated through the daily programmes of the mass media and particularly via news. The national and international agenda emerge from daily mass media processes of production and consumption. Both the concept and feeling of nation and of the world are also articulated in the production and consumption of media. Along the same lines, citizens gradually define their own styles and ways of communicating and whatever unites them or differentiates them, the tolerance they are capable of showing, or the intransigence and solidarity they can muster. The general collective sense of trust or mistrust is filtered through the observation of events and images shown by the media.

Mass media are a source of production of both their own cultural modernity and the political morality which supports it. Although global, media have a stronger position in countries with weak governmental, political and social institutions, where education, family, social organizations, and political parties do not contribute to the creation of independent and democratic citizens, but emphasize an ethos of survival and submission to power, thus generating an individual and collective consciousness ready to legitimize totalitarian rule, clientelism, disorder and corruption. Whenever the counterweight of the three powers and civil society do not function properly, mass media play an important role vis-a-vis information and current opinion trends. However, the media seldom tend to admit their responsibility for that pre-established (and probably unintentional) role. They need to play a political and social supervising role, which they do not always know how to perform.

In modern societies, mass media are considered the public sphere in which topics of common interest are presented and defined, especially on television. The purpose of the news is to define what is public and 
what is not - with even private events potentially defined as public. Thus the media can confirm or question beliefs, the credibility of styles, celebrities and events. Public opinion is formed, and has a great influence over politics, since it will end up being a key factor in elections. Nevertheless, this 'public sphere' is not nearly as homogeneous as it is normally presented to us. Rather, it hides different trends and disagreements within the public opinion. In this sense, Nancy Fraser (1997) proposes the existence of publics and counter-publics, 'strong' and 'weak' publics. Without the existence of a public space where plurality is expressed, it will not be possible to generate a democratic political culture. It will also not be possible without the participation of the citizens, since without them there is a risk for 'opinion' to become more private than public. Along these lines, we can say that in our countries the public sphere is a sort of vacuum, because a 'commons' is never securely constituted.

We confront the challenge of moving towards a new and more democratic public opinion, not a mere reflection of the instantaneous collective climates defined by surveys and opinion polls. By this I mean a public opinion based on the participation of diverse recognized actors, including the citizen: it should be deliberative, work in relation to the voter representation, search for both consensus and dissent, be supplied with information, have an active dialogue with the power structure by using multiple available languages, and finally have a notion of actuality that goes beyond news updates (Miralles, 2000). Therefore, we are talking about multiple publics, all engaged in public discussion and debate, preparing new ways of expressing ideas but without homogenizing them, and yet capable of reaching agreements and/or bringing pressure to bear on other factions. In this sense, civil society surveillance is an innovation directly connected to the public sphere.

For these reasons, mass media are important in the struggle against authoritarian rule and on behalf of democracy; or, on the contrary, in the legitimization of dictatorships. For many years in Peru, for example, many different media yielded to the power structure by hiding the truth and extolling authoritarianism, without the slightest sign of protest on the part of civil society. Moreover, 70 per cent of the citizens supported the autocrat Fujimori. This was a factor that prevented the regime from falling for years, and provided the opportunity for his unconstitutional re-election. But at the same time, investigative journalists' actions on behalf of democracy also managed to strike blows against these same anti-democratic forces. Thus freedom of speech is fundamental to democracy. But this cannot be established by violating other freedoms. 
Given the fact that different basic freedoms are likely to come into conflict, the institutional rules which define such freedoms should fit into a coherent frame of freedoms. These freedoms are not infringed upon when they are regulated in the way they should be in order to fit them into a coherent outline, and are thus adapted to certain conditions necessary for their lasting practice. As long as what I call 'basic margins of application' of the basic freedoms are supplied, the principles of justice are satisfied. For example, a rule of order is essential to regulate freedom of speech. Without a general acceptance of investigative procedures and the precepts of reasoned debate, freedom of speech cannot fulfil its aim (Rawls, 1997: 37-8). Latin America is a paradox in this sense, in that what is really being defended there is entrepreneurial freedom, that is, the right to do anything to make money.

\section{Societies and cultures in movement}

However, mass media are not the only space where public opinion is constructed. For instance, we still find a strong tendency to understand and identify 'culture' with ethnic and folkloric artistic expressions. This approach has been constructed on the basis of a variety of opposing viewpoints, such as tradition versus modernity, the West versus its negation, social organization versus traditional customs, beliefs versus pragmatism, loyalty versus cultural betrayal, the community versus the masses. Little has been done in order to identify and understand different cultural sensitivities, different languages (oral, audiovisual, not only idiomatic), and much less concerning people's visualizations of themselves and others. Communication is rarely seen in all its dynamism, since its articulations with other social problematics are not well understood, whether in its dialogue with economics, its relationships with the political, or its role in representations of oneself and others. We need to re-think the connection between communication and identity, since identity is traversed by individual adventures and specific biographies; it is not the mere reflection of collective identities. It is these biographies which ultimately constitute our cultural communities, influencing the public sphere and the future direction of our world.

The perspective we are criticizing here emerged as a counter-position to the legitimization of so-called 'high culture' as the only one universally accepted, thus severely discriminating against 'those with low culture', understood in terms of the low educational levels and economic shortcomings of certain cultural groups. That perspective still 
prevails among some conservative intellectual sectors. To a degree this identification between ethnicity and culture was revolutionary, and, especially in Latin American countries, called into question the primacy of the dominant sector's cultural perspective, given that the cultures of indigenous groups and popular urbanized sectors, mingling within the framework of modernity, produced sites of encounter and cultural coexistence of intense complexity and diversity. On the basis of these new sites of cultural encounter, an attempt was made to legitimize 'cultural rights', which were now welcomed. Cultural diversity was given space and visibility. Regrettably, however, the defenders of ethnic cultures have moved towards protectionist visions and attitudes, hiding the syncretism and the complexity of the cultures-in-movement that we are experiencing nowadays. This 'anthropological' line of thought is limited when trying to understand the tangled cultural interactions that happen in today's world.

Though the search for a genuine, autochthonous, communal life is still on, at the same time many actors in this process willingly adopt any new format which will help them to live in common, thus avoiding exclusion and marginalization. The different nuances which modernity superimposes upon tradition reflect the emerging scenario of accommodations and differences. Today local community celebration has become a television or radio performance. Music in its pure form is extinct, its current richness determined rather by mixtures and new creativities. Intense levels of identification with melodrama emerge from the telenovela performance of a poor man who finally triumphs. Culture is no longer something fixed and essential; it is rather nomadic and open to change. Today, though culture feeds on the past, it lies in the present, and looks towards the future. We cannot forget, nevertheless, that it is still evident that some cultural forms derive from the history of colonization (Alfaro, 1986; Blondet et al., 1986). All this reveals a cultural landscape in constant movement, where the conceptions of territory and temporality vary in the search for a new identity that does not stay inert, but whose very nature is dynamic.

This underscores the strong relationships between the social and the cultural, the former being a very important factor of re-allocation and cultural change, due to two main trends: on one hand, the fight for survival by broad sectors of the Latin American population, permeated by submission and victimization, but with a strong element of experimentation and creativity, and, on the other hand, the daily experience of social exclusion, which leads many sectors of the population to make cultural investments in order to obtain equality and 
recognition in both the real and symbolic spheres, including mass media. This has led to the formation of two large movements of exchange between traditional cultural actors: on the one hand, those who react by forming collectives and engaging in collective action (Ecuador or Bolivia); on the other hand, those who search for different ways of integrating with modernity (Peru, Guatemala). Such tendencies can also co-exist in a single country, such as Mexico. There are multiple cases of poor peasants who adopt non-traditional production strategies to be able to survive and progress. Though many migrants maintain some aspects of their original cultures, which they bring to large urban centres around the world, the adaptation mechanisms end up exposing them to other cultural contingencies which require more study.

Market logic has permeated people's lives, including indigenous peoples, no matter how isolated and self-defensive they are. This logic penetrates everybody, though in different ways. It even defines both the individual and collective cultural capitals of a given society. In this sense, the growing poverty on the continent has now acquired new meanings, because even if Latin American individuals and collectives flirt with the idea of integration with the global market for survival, it so happens that the results are not those which were promised, thus sowing frustration. It is continuously possible to see this market displayed on TV and in the newspapers, not only from advertising, but also from the daily information and entertainment offerings. The 'we' becomes de-territorialized and diversified in contact with mass media. The search for comfort as well as its symbols and access to economic transactions have configured new subjects, with different demands on the market, depending on their social status. Though social position and cultural heritage determine more specific individualities, the mode of insertion into local and foreign markets and their new technologies produces distinct and new meanings that are more global than local. These meanings are now establishing new referents by which people organize their lives, and articulate their hopes, values and sensibilities.

At the same time, the importance of nation and its precise borders has diminished with respect to new powerful interests. The result is a series of global and local spheres that do not necessarily take national spheres into account. This climate of economic globalization and cultural change redefines the subject, not only as a national citizen, but as a world citizen, and culture becomes de-territorialized in its production and consumption (Ortiz, 1997). As massive waves of international migration make clear, globalization does not necessarily mean either integration or full citizenship; on the contrary, inequality and exclusion 
become global phenomena. Culture does become global, but this does not mean that it enhances diversity, simply that it reaches all of us, symbolized, for instance, in the communicative act of sitting in front of a computer and connecting to the internet. The cultural encounters allowed by cable television or the inclusion of world music in each country and community have yet again called into question the matter of territorial borders of cultural identities. These are changes that have come hand in hand with technology. So we can say that 'the globalization of culture becomes apparent in the midst of daily life' (Ortiz, 1997: 18).

Nationality, as a referent of political identity, has also suffered decentrings and displacements, both in its real and symbolic renditions. The nation-state as a cultural project in many Latin American countries has not taken root. But, at the same time, the new social movements such as human rights, environmental and feminist movements - act with the primary goal of influencing change at the national level. On the other hand, the agency of civil society has emerged beyond national borders. Although new spaces of contact that traverse national borders are being created, this fact does not hinder national autonomies. This seems to confirm what many Latin American authors have observed, in terms of how globalized economy and culture influence the re-location, the anchoring in the local and regional of a sense of belonging and cultural production. It is interesting to note, for instance, the prevailing indifference shown by many citizens in the activities of national congressmen (Alfaro, 2003), while at the same time they seek out the opportunity to monitor their local and regional authorities.

Mass media are an important part of such formations, linking different areas of human knowledge and encounter. Seeing, reading, and hearing constitute active forms of participation, even if clear social and political responsibilities do not necessarily emerge from them. Although the mass media perceive their audiences as basically consumers and not citizens, the messages and their images imply perceptions and subjective assessments of both one's own and others' cultural values, thus blurring the boundaries between the vernacular and the foreign. Audiences are rarely addressed as members of local or national communities, but as people connected to certain media products and genres on the basis of the pleasurable encounters with specific age groups, educational levels, social sectors, gender or musical taste.

In the sphere of mass media, new cultural rearrangements are produced from an individual interpretation, which is later shared with others, allowing the placement of oneself in different loci or groups; 
thus one's own cultural heritage loses centrality. Lifestyles are now important when defining new cultural groups, cultural groups that did not exist before as such but still emerge in their own cultural constructions. A hybrid mixture of classes both combine and then influence such changes, tending to blur the limits between one space and another, and also between the media's competencies and pertinences, styles, disciplines, and ways to access common good and happiness. New narratives of life now take place; thus dramatization, humour and testimony gain influence, suffused with a sense of the 'spectacular'.

The relationship between collective and individual culture has also undergone transformations, since both have become more complex but neither has been eliminated. This calls into question our notion of the identity of the cultural subject, and how this new subject reallocates $\mathrm{him} /$ herself within politics. Modern life offers a wide variety of interactions, behaviours, and new values which are then stored and processed unequally. Therefore, it becomes impossible to approach the individual subject as a pre-established unity; the new articulation of the individual and the collective subject emerges from the multiplicity of encounters between this subject and others throughout everyday life. In this sense, Chantal Mouffe questions the homogenizing vision of the subject. She asserts:

The isolated individual can be the carrier of such multiplicity: to be dominant in a relationship and subordinate in another. We can therefore conceive the social agent as an entity constituted by a group of subject positions which cannot ever be completely fixed in a closed system of differences; an entity constituted by a diversity of discourses, within which no relationship is necessary but rather a constant movement of overdetermination and displacement. (Mouffe, 1999: 110)

Seeing oneself in the media means looking for diverse images of peers, which are usually not necessarily configured with respect to a cultural identity of an ethnic nature, but rather according to other subject positions emerging from economic, social, and political participation. But, at the same time, it means seeing the heterogeneity of one's own identity, and the political responsibilities which emerge from it. It would seem that today the desire to learn to live together, as nonessentialized individualities, is a new, strongly mobilizing force for cultural association and political action; Latin America is looking for ways of interaction and mobilization that take into account some aspects of individuals, but aspects traversed not by the traditional identity markers of beliefs, languages or customs, but more based on different personal and collective identity axes. 
Citizens lost in a cultural scene without dialogue: trends in media cultures

What then is the new role of the mass media in this context? How does one represent these societies in movement so that they can really express themselves and go forward? Does one only deal with the mere bringing to light of particular, isolated complaints? How do we reconstruct our passion for democracy, turning it into real strength and not only into a mere mobilizing resource useful for a particular moment? How can we bring together the sense of justice and the idea of participation? How do we reunite the social links and the new notions of community, notions that emancipate the individual and teach us how to live in solidarity? How do we connect political life with a democratic cultural project? The problem is that these questions have not yet been asked.

Still, I rather prefer to think of civil society as an articulating force capable of generating new leadership in the political life of the country, thanks to its social investment in relationship among citizens. It is not a tangible entity, but rather a group of movements and institutions that take charge of social life and its incidence in politics. Such a relationship is not based on the notion of representation, but rather on a programmatic knowledge of the country and its different actors, based on the experience of previous political action. The relationship depends on the willingness to change and solve the problems which afflict the majority of the people. It is the space where different social forces and professional knowledge meet. It is intimately linked to both the collective and individual actors in the economic and cultural spheres and counts on a basic solidarity. It would be the engine that drives the nation, without ignoring the state, but rather talking with and to it, both critically and proactively.

That is why civil society's direct relationship with citizens is a key factor. And

it has an additional essential meaning, which is the possibility to create a non-governmental milieu which includes a series of public spheres, productive and domestic units, organizations of mutual assistance and services based upon the community, all of them legally guaranteed and selforganized. (Keane, 1992: 33)

These factors, once organized, can become a political force which defines problems, gives opinions and proposes and assumes leaderships, without denying the diversity from which it is constituted.

But our mass media, ubiquitous among government and those 
dispersed and disoriented citizens whose sectarian and symbolic representations proceed spontaneously and separately, have not developed the ability to interpret and to systematize these diverse interests. Our media do not even consider their audiences as citizens, nor do they know the political cultures which sustain them. Even worse, between the importance given to the news of the moment and the excessive focus on the official political actors, a consensual and common construction is not possible. Citizens' sense of belonging to society gets thinner and thinner, to such an extent that it no longer matters who the elected president is, or what his/her governmental programme will be, because we now only expect social results. There is much despair, discredit and political apathy. Thus, nothing belongs to anybody, except to the rulers. Regrettably, civil society is thus projected on to the media from the point of view of experts, and not necessarily from the real changes and projects that are being worked on. That is, participation becomes an individualized and technical affair.

In fact, the malaise facing politics is so generalized that, evidently, we have to rethink the democratic model so that processes of collective fury and irritation find spaces for expression which do not exist today. Educational strategies should be aimed at this goal, and information should feed these new spaces of dialogue. Civic participation has to be closely linked to learning to communicate. Today, civic forums have moved into the homes, into the bars and into private conversation. The notion of 'we' becomes almost impossible, since for many it is more a question of dividing and fighting. This last void is fodder for social explosions, because the citizen realizes that $\mathrm{s} / \mathrm{he}$ does not have a public voice, that $s /$ he is not heard, that $s /$ he requires a visibility which is not granted to him/her, that $\mathrm{s} /$ he needs political power, needs to be in a dialogue with power. Democratic participation still occurs in places and even in some media outlets which are not heard by all, so that they don't have enough leverage to generate social change. The formal model of democracy does not allow society to generate dialogue, the necessary fuel for political action.

But perhaps the most worrisome scenario emerges from the trend to privatize all social and political life, thus generating a stampede of individuals toward an institutionalized framework that looks the other way - never toward its citizens. All Latin American countries suffer from such a problem, though in a different manner. For example, we have denied ourselves the right to see ourselves, and recognize who we are, where we are, and what we can do.

The cultural challenge is urgent for the political transformation and 
democratization of Latin American countries, and for the generation of new deliberative and inclusive communicative policies. Strengthening the links of a possible 'we' which is not homogeneous and admits differences, yet is not unequal, presupposes a mass media inserted into a new cultural project that, unfortunately, we are not yet capable of constructing. In this sense, communication also inherits a new challenge to come up with proposals in terms not only of new discourses, but also in terms of the need to establish a new relationship with media consumers, who are also citizens of an ethical democracy involving everyone in its construction. The social and cultural links are to be created and turned into political capital capable of rebuilding the entire social fabric. Here, political and intellectual sermons are worthless, because what we really need to do is to engender a new collective action, a new collective journey.

\section{Note}

1 Translated by Emma Cristina Montaña R., Patrick D. Murphy and Clemencia Rodríguez.

2 Used by the team Desarrollo Humano in Chile: Nosotros los chilenos: un desafio cultural. Report (2002), the United Nations for Development, Santiago de Chile.

\section{References}

Alfaro Moreno, R.M. (1986) De la conquista de la ciudad a la apropiación de la palabra. Lima: Calandria y Tarea.

Alfaro Moreno, R.M. (2001) Comunicación y política: Viejos conflictos, nuevos desafíos. Bogotá: CEJA.

Alfaro Moreno, R.M. (2003) Ciudadanos de a de veras: Una propuesta de vigilancia de la gestión pública desde un enfoque comunicacional, 2nd edn. Lima: Calandria.

Alfaro Moreno, R.M., Pinilla, H., Tellez, R. and Gogin, G. (1990) Cultura de masas y cultura popular en la radio peruana. Lima: Calandria y Tarea.

Blondet, C., Degregori, C.I. and Lynch, N. (1986) Conquistadores de un Nuevo Mundo: De invasores a ciudadanos de un nuevo mundo. Lima: IEP.

Brunner, J.J. (1994) Cartografías de la modernidad. Santiago, Chile: Dolmen Ediciones.

Cortina, A. (1977) Ciudadanos del mundo: Hacia una teoría de la ciudadanía. Madrid: Alianza Editorial.

Fraser, N. (1997) Iustitia interrupta: Reflexiones críticas desde la posición postsocialista. Bogotá: Universidad de los Andes.

García Canclini, Néstor (1989) Culturas hibridas: Estrategias para entrar y salir de la modernidad. Mexico City: Grijalbo.

Keane, J. (1992) Democracia y sociedad civil. Madrid: Alianza Universidad.

Miralles, A.M. (2000) 'Una idea de periodismo público', Voces Ciudadanas: 53-64. Medellín: Universidad Pontificia Bolivariana. 
Mouffe, C. (1999) El retorno de lo político: Comunidad, ciudadanía, pluralismo, democracia radical. Barcelona: Paidós.

Orozco, G. (1996) Televisión y audiencias: Un enfoque cualitativo. Madrid: Universidad Iberoamericana and Ediciones La Torre.

Ortiz, R. (1997) Mundialización y cultura. Buenos Aires: Alianza Editorial.

Rawls, J. (1997) Sobre las libertades. Barcelona: Paidos/I.C.E./U.A.B.

Rey, G. (1998) Balsas y medusas. Visibilidad comunicativa y narrativas políticas. Bogotá: Cerec-Fundación Social y Fescol.

Touraine, A. (1998) Qué es la democracia? Buenos Aires: Fondo de Cultura Económica.

\section{Biographical note}

Rosa María Alfaro Moreno is founder of the Social Communications Associations 'CALANDRIA', a Latin American non-governmental organization with an emphasis on communication and social change. She is also founder of the Social Communication Citizen Control Group, a national project in which citizen participation in monitoring the media is encouraged and facilitated. Her books include De la conquista de la ciudad a la apropiación de la palabra (From Conquering the City to Appropriating Words), Interlocución radiofónica (Radio Production) and Ciudadanos de a de veras (Honest to Goodness Citizens). At present, she is Director of the Communication and Development graduate programme at the Universidad de Lima.

Address: Universidad de Lima, Peru. [email: ralfaro@terra.com.pe] 